\title{
Assessing Diversity Levels in Selected Wine Regions of South Moravia (Czech Republic)
}

\author{
Lucia Ragasová $^{1 *}$, Tomáš Kopta ${ }^{1}$, Jan Winkler ${ }^{2}$, Robert Pokluda ${ }^{1}$ \\ ${ }^{1}$ Department of Vegetable Growing and Floriculture, Faculty of Horticulture, Mendel University in Brno, \\ Valtická, Lednice, Czech Republic \\ ${ }^{2}$ Department of Plant Biology, Faculty of AgriSciences, Mendel University in Brno, Brno, Czech Republic
}

Received: 9 November 2018

Accepted: 26 March 2019

\begin{abstract}
Agriculture, including the viticulture practices of the 1950s-1980s, has led to a great decrease in diversity and simplification of the landscape. Such an environment does not support biodiversity, thus does not provide an ecosystem service, and is very vulnerable to changes and pest attacks. This agricultural production needs high inputs and so cannot be considered to be sustainable. The aim of our work was to assess the diversity of the vineyard sites of South Moravia according to proportions of noncrop vegetation, cropland and bare soil vineyards. The relationship between land-use and locality was analysed with Canoco 5 software for ordination analysis. Areas with bare soil vineyards, cropland and intensive orchards can be regarded as areas that decrease the diversity of the landscape, while elements such as non-crop vegetation and extensive old orchards support and increase landscape diversity. This landscape with high diversity provides an environment for a number of plant and animal species, which leads to the preservation and support of the biodiversity of the whole ecosystem. The highest landscape diversity was assessed in the Mikulov region, with 12\% non-crop vegetation and the Strážnice region (8\%), while the worst situation is in Valtice region, where 53\% and in Znojmo $43 \%$ of the total are designed for grapevine production (vineyard sites) and used as cropland.
\end{abstract}

Keywords: landscape diversity, non-crop vegetation, vineyards, South Moravia, RDA ordination analysis

\section{Introduction}

The conservation of biodiversity is crucial not only for nature conservation, but also for maintaining or increasing the sustainability and stability of agricultural production. In agricultural systems, biodiversity provides important ecological services, such as recycling of nutrients, storage of carbon, management of beneficial organisms and pests, crop pollination and regulation of the local hydrological cycle and microclimate $[1,2]$.

Grape production, like other agricultural production, still remains strongly monocultural in many parts of the world [1]. Monocultures can have advantages, but over the longer term lead to more serious economic and environmental problems [3]. Viticulture relies on a high use of inputs [4]. Pesticides are brought in first to control pests and diseases, then fertilisers, 
depending on the expected yield level, and water in dry localities. Aside from overall eutrophication of the ecosystem with NOx, sulfur oxides, heavy metals and farming change (pasture minimisation), a significant contribution to the great landscape diversity decrease in the South Moravian region has also come from viticulture. The extensive application of a suite of nonselective insecticides with high toxicity (DDT in the 1950s and 1960s, organophosphates and carbamates in the 1970s, synthetic pyrethroids in the 1980s-1990s, insect-hormone based pesticides, e.g., diflubenzuron in the 1990s-2010s) has made the situation for non-targeted insect species critical. Massive use of herbicides, ruderalisation, the consecutive erosion of soils with high doses of mineral fertilisers and the destruction of native non-crop vegetation have contributed to this bad situation [5]. Research on the rapidly expanding grape production in California has resulted in drastically decreased diversity, abundance and activity of natural enemies of pests due to the removal of vegetation that provides critical food resources and overwintering sites necessary for the longevity, reproduction and survival of many predators and parasites [6,7]. Homogenisation of vineyards increased their vulnerability to insect pests and diseases, which can be devastating when they infest uniform and homogenous large-scale monocultures [7].

In contrast, an agroecological approach to viticulture should mobilise natural control (e.g., pests and diseases) within the agroecosystem in order to enhance the provision of ecosystem service and reduce inputs [7, 8]. Non-crop vegetation can defuse the negative effect of monoculture and increase the level of biodiversity in agroecosystems [9]. Maintaining or increasing natural and semi-natural habitat in the landscape provides higher effective pest control $[10,11]$. In the South Moravian region the first positive changes came with the introduction of alternate greening in the 1990s and the successful progress of biological control use by Typhlodromus pyri, when viticulturists started to realise the toxic effects of pesticides. In the following years, through several projects, conversion to integrated production (IP) successfully started, resulting in 12000 ha of IP vineyards in the Czech Republic $(2 / 3$ of the total area of vineyards) in 2005 . Ecologically controlled vineyards with non-crop vegetation and flowering vegetation can serve as migration corridors

Table 1. Evaluated wine-producing municipalities and vineyard sites within chosen regions according to Decree No. 254/2010 Coll. [13].

\begin{tabular}{|c|c|c|c|}
\hline Region & $\begin{array}{l}\text { Wine-producing } \\
\text { municipalities }\end{array}$ & Evaluated vineyard sites & $\begin{array}{l}\text { Number of evaluated sites/ } \\
\text { total number of vineyard } \\
\text { sites in municipalities }\end{array}$ \\
\hline Bzenec & Bzenec, Domanín & $\begin{array}{l}\text { Hašenky, Horní hory (I-IV), Kneží hora (I-III), Novosady (I-II), } \\
\text { Prostřední hory (I-III), Starý hrad (I-II), Zadní hora, Humna (I- } \\
\text { III), Krefty, Pusté, Slíny, Stará hora, Vinohrádka }\end{array}$ & $13 / 13$ \\
\hline Strážnice & $\begin{array}{l}\text { Strážnice, Petrov, } \\
\text { Sudoměřice }\end{array}$ & $\begin{array}{c}\text { Novosády zadní, Růžené (Petrov), Tmice, Veselé, Dolní Hory, } \\
\text { Frisáky, Horní hory, Podkovné (I-II), Růžené (I-II) (Strážnice), } \\
\text { Stračinky, Svárové, Teplé (I-III), Žerotíny (I-III), Díly za zahra- } \\
\text { dou, Staré hory, Vápenky }\end{array}$ & $16 / 16$ \\
\hline $\begin{array}{c}\text { Velké } \\
\text { Bílovice }\end{array}$ & $\begin{array}{l}\text { Velké Bílovice, } \\
\text { Moravský Žižkov }\end{array}$ & $\begin{array}{c}\text { Sahary, Stará hora (I-II), Dlouhá hora (I-II), Nová hora, Obecní, } \\
\text { Obory, Pod Belegrady (I-IV), Přední hora (I-II), Širkoá hora (I- } \\
\text { II), Vinohrádky, Zadní hora (I-III) }\end{array}$ & $\begin{array}{c}11 / 12 \\
\text { (missing site: Slovenské) }\end{array}$ \\
\hline Valtice & $\begin{array}{l}\text { Valtice, Úvaly u } \\
\text { Valtic }\end{array}$ & $\begin{array}{c}\text { Culisty-Dluhé, Hájky, Hintertály, Horní čtvrtě (I-III), Jižní svahy } \\
\text { (II-III) (Valtice), Kačsdorfské pole, Knížecí vyhlídka (I-II), } \\
\text { Nad peklem (I-III), Pod Reistnou (I-II), Sacny, Terasy u hranic, } \\
\text { Terasy u Křížového sklepa (I-II), U sv. Anny, Hůrka, Jižní Svahy } \\
\text { I (Úvaly u Valtic), Kamenné hory, Nad mlýnem, Pánsky kopec } \\
\text { (I-II), Pod sluneční horou, Sonnenberg (I-II), Staré hory, U } \\
\text { cihelny, Za humny }\end{array}$ & $23 / 23$ \\
\hline Mikulov & $\begin{array}{l}\text { Mikulov, Bavory, } \\
\text { Březí u Mikulova }\end{array}$ & $\begin{array}{l}\text { Anenský vrch, Maliny, Pod Pálavou (I-V), Pod státní, Růžová } \\
\text { (I-II), Slunečná, U rybníčka (I-III), Liščí vrch, Ořechová hora } \\
\text { (I-II), Brněnská, Mariánsky kopec (I-II), Milovická (I-VI), } \\
\text { Pod Mušlovem (I-III), Pod Svatým kopečkem I, Pod Svatým } \\
\text { kopečkem II, Pod valtickou, Šibeniční vrch (I-III), Turold (I-III), } \\
\text { Valtická (I-II), Za cihelnou (I-III), Za Turoldem (I-III) }\end{array}$ & $21 / 21$ \\
\hline Znojmo & $\begin{array}{l}\text { Chvalovice, Ha- } \\
\text { vraníky, Hnanice, } \\
\text { Šatov, Znojmo, Pod- } \\
\text { molí, Nový Šaldorf- } \\
\text { Sedlešovice, }\end{array}$ & $\begin{array}{l}\text { Dlouhé díly, Skalky (I-IV) (Havraníky), Staré vinice (I-II), Flád- } \\
\text { nická (I-IV), Knížecí vrch (I-IV), U Chlupa (I-III), U Kapličky, } \\
\text { Dívčí hora, Nad sklepy (I-II) (Nový Šaldorf), Kraví hora (Nový } \\
\text { Šaldorf), Nad sklepy (Chvalovice), Kraví hora-Zahrádky (I-II), } \\
\text { Šobes, Na vinici (I-III), Peklo, Skalky (I-III) (Šatov), U bunkru, } \\
\text { Gránice, Hajden, Horní Leska (I-II), Kraví hora (I-III) (Znojmo), } \\
\text { Křivánky, Lajtny, Načeratický kopec (I-VII), Pod lesem (I-IV), } \\
\text { Rajská zahrada, Třešňovka, U sv. Urbana, Za křížom }\end{array}$ & $29 / 29$ \\
\hline
\end{tabular}


for fauna while keeping sufficient yield and quality of production $[5,7]$.

Nowadays in the Czech Republic the total area of vineyards amounts to 17.7 thousand hectares with more than 18 thousand registered farmers [12] in 383 wineproducing municipalities. In South Moravia, with its 308 wine-producing municipalities ( $80 \%$ of the total), vineyards are an important part of its landscape [13]. The approach that farmers take and the policies chosen affect the impact of viticulture on the landscape.

Analyses based on RDA ordination are used for evaluation and analysis of ecological data on different levels - from diversity of genes to landscape patches. Baumgartner et al. used distance-based RDA analysis to examine the effect of cover crop systems on weed communities in California vineyards [14]. The relationships between beneficial insects and flowering plant species [15] or between pollinators and landscape complexity, fallow field age and management practices [16] have also been analysed using RDA ordination.

The aim of this work was to access and compare the diversity of 6 important wine-producing districts and compare the differences between them, especially in non-crop vegetation proportions, bare soil vineyard appearance and land-use.

\section{Material and Methods}

In the Czech Republic a vineyard site is a legislatively stated area designated for growing grapevines. A wineproducing municipality is defined as a municipality that contains at least one or more vineyard sites [17]. During the vegetation period (April-September) in years 2016 and 2017 we evaluated the land-use of 113 vineyard sites with a total area of almost 7000 hectares in 6 wine-producing districts of South Moravia: Bzenec, Strážnice, Velké Bílovice, Valtice, Mikulov and Znojmo. The evaluated wine-producing municipalities and vineyard sites that are included in the 6 regions are in Table 1. Some vineyard sites consist of several locally separated areas, which were evaluated separately and distinguished by the numbers I-X.

Every vineyard site was evaluated once during the vegetation season in order to assess vegetation in vineyards. Within vineyard sites several land-uses were distinguished: vineyard, cropland (mostly corn, wheat, oilseed rape or sunflower fields), non-crop vegetation (forests, groves and meadows) and other use (incl. intensive orchards, gardens, roads and buildings). In vineyards the type of vineyard greening was evaluated as bare soil, and other management (alternate greening, full area cover crop). Data were recorded in real time at the site for every parcel with the special GIS application 'Naše Mapy' (HF Biz s.r.o.) using land register data, ortho-imagery maps, ZM10-ČÚZK (Cadastre of Real Estate) and GPS coordinates (Fig. 1). Exported data from the GIS application provides data about the area $\left(\mathrm{m}^{2}\right)$ for each type of land-use for each parcel according to land register data.

Proportion of Non-Crop Vegetation, Crop Land and Bare Soil Vineyards in Wine-Producing Regions

The total area of every kind of land-use was calculated as the sum of areas (in $\mathrm{m}^{2}$ ) with given landuse from exported data and expressed as a percentage of total vineyard site area per region. Percentual proportion graph (Fig. 2) shows the land-uses that effect the landscape diversity most. The other uses include: other than bare-soil vineyards, orchards, hobby gardening areas.

\section{Relationship of Land-Use to Locality (Region)}

The software chosen for analysis in this research, Canoco 5, is designed for explaining and better

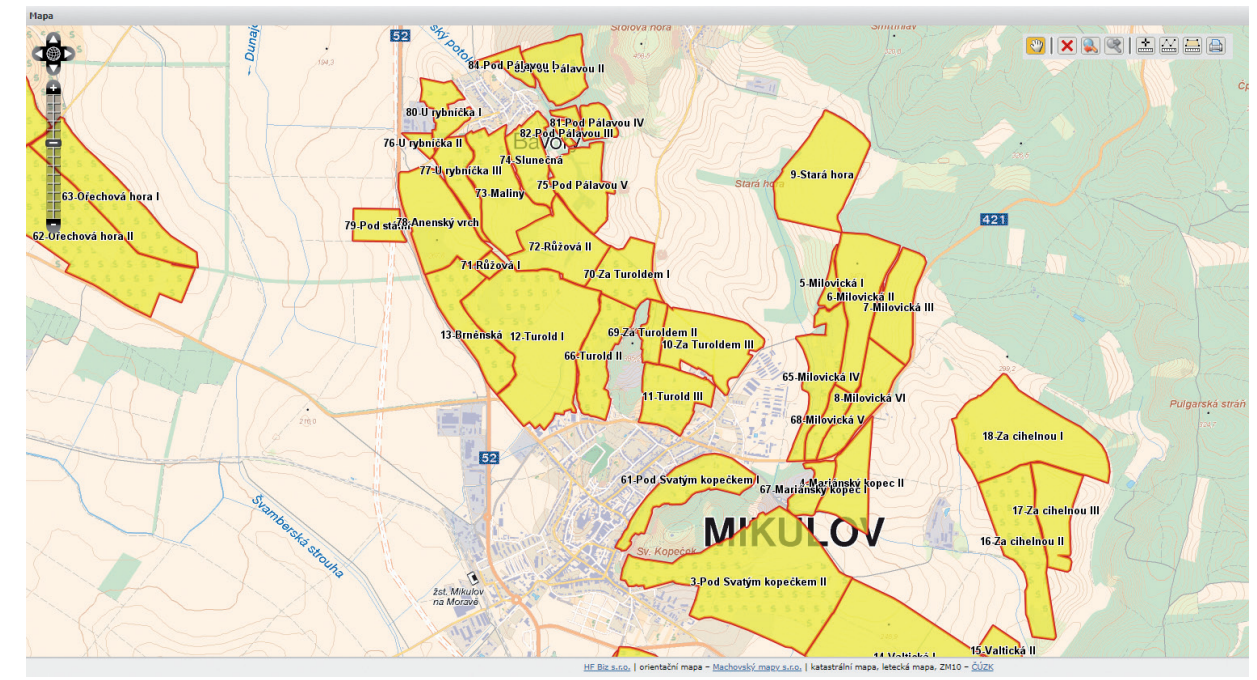

Fig. 1. Picture of GIS map portal 'Naše mapy’ (HF Biz s.r.o.), vineyard sites of the Mikulov region. 
understanding the structure and pattern in nature by using multivariable analysis of ecological data. Canoco methods originated in the field of ecology. Ordination analysis with Canoco can provide insights into the structure of biological communities and into the impact of natural and human-induced environmental disturbances on biological assemblages [18].

The relationships between land-use types and vineyard regions were analysed by redundancy analysis [18]. This method, based on linear gradient response, was chosen as an appropriate method after preliminary detrended correspondence analysis, where the length of the main gradient (first axis) was found to be short (2.22 units of standard deviation), therefore recommending linear methods as appropriate. The Monte-Carlo permutation test, calculated with 999 permutations, was used for statistical evaluation of the results. Data analysed for estimating diversity of landscape within 6 different localities were non-crop vegetation, which has a significant positive effect; bare soil vineyards and crop lands, which are considered as factors that decrease diversity. The used analysed data were in hectares.

\section{Results and Discussion}

\section{Proportion of Non-Crop Vegetation, Cropland and Bare Soil Vineyards}

The highest proportion of non-crop vegetation was assessed in Mikulov (12\%) and Strážnice (8\%), while other regions have a proportion of non-crop vegetation between 5 and 7\%. A very high percentage of cropland use in vineyard sites occurs in Valtice (53\%), the Znojmo region (43\%) and Bzenec (37\%). The lowest use of land as cropland is in Mikulov (17\%). Bare soil vineyards are mostly located in the Mikulov region (12\%) and least often in Bzenec and Valtice (3\%) (Fig. 2). Other uses not included in the diversity analysis are highest in Strážnice, where this area is mostly used as hobby gardening areas, orchards and vineyards with alternate greening, and in Velké Bílovice, where there is a high proportion of alternate greening vineyards and areas with intensive orchards or buildings.

The high proportion of non-crop vegetation in the Mikulov region (12\%) (Fig. 2) is related to the location of the Pálava Protected Landscape Area (CHKO). CHKO Pálava is a protected area of $83 \mathrm{~km}^{2}$ located in the South Moravian Region and it is also a UNESCO biosphere reserve. On the complex of 140 ha of vineyards at the base of the Svatý Kopeček u Mikulova hill slope since the year 2009, an international project has been realised with the aim of recreating an environment suitable for many plant and animal species and providing for the migration of species between the protected native biotopes of Pálava Hill, thus supporting the biodiversity of the region through integrated or ecological vineyard management, which includes the use of cover crops, biological control (natural enemies, pheromones, etc.) and the protection of non-crop vegetation [5]. A study of agricultural production farms in Switzerland [19] and England [20] shows that the average of non-crop vegetation within organic farms covers $22 \%$ and in conventional $13 \%$ of the agricultural area of the farm [19]. Compared to these numbers in South Moravian vineyards, it is generally a lower proportion of noncrop vegetation. According to the IOBC (International Organisation for Biological and Integrated Control), 15\% of non-crop vegetation within farmland is recommended [21]. However, locally within a few vineyard sites noncrop vegetation covers from almost $30 \%$ to more than $50 \%$ of the site area (e.g., Horní hory II (Beznec), Terasy u Kř́ížového sklepu II, Terasy u hranic (Valtice), Pod Pálavou, U rybníčka (Mikulov) and Skalky

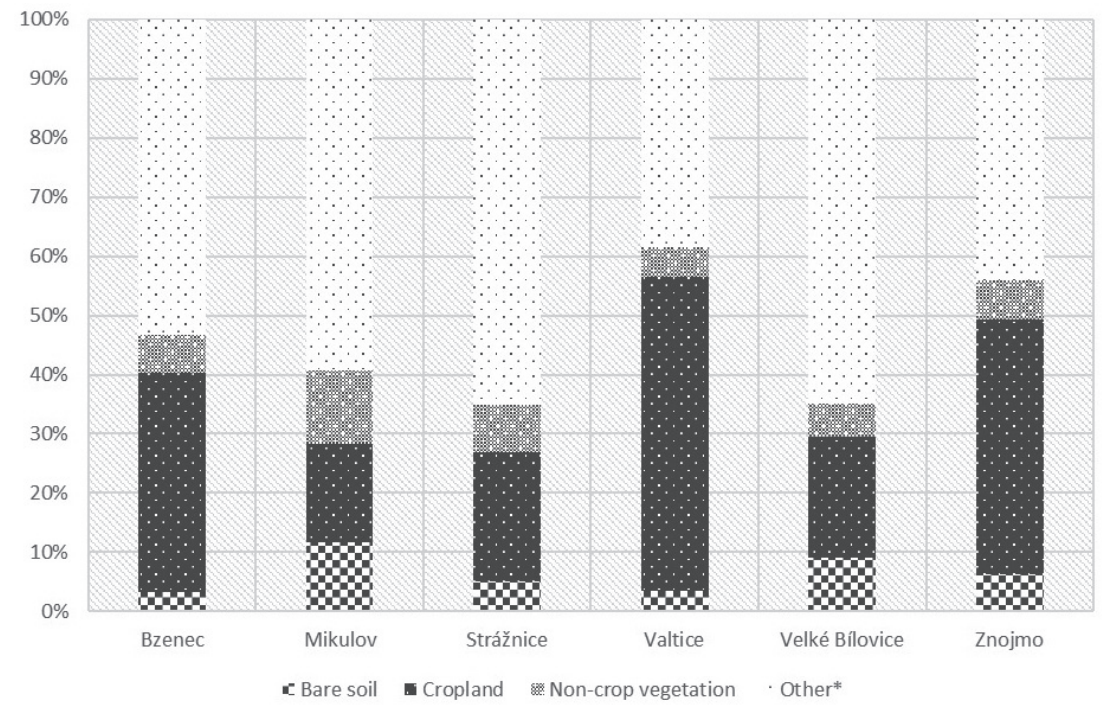

Fig. 2. Proportion of chosen land-use per total area of every region's vineyard site area (in \%) (*other includes vineyards with alternate or full area cover crop; intensive orchards, gardens and roads and buildings). 
II-Havraníky (Znojmo)). Such a high proportion of noncrop vegetation can be found in the Alto Duoro region in Portugal, which is not only a UNESCO heritage site, but also has special importance in maintaining functional biodiversity and an ecosystem service in the region [1].

Both the Mikulov and Velké Bílovice regions have largest total area of vineyards (more than 750 ha) from 6 evaluated regions. The high proportion of bare soil vineyards in those two regions points to new, eventually renewed vineyards, which usually keep bare soil for the first three years after planting. Anyway, older vineyards can still be found keeping permanent bare soil, which can intensify the already serious problem with soil erosion - especially in vineyards on moderate slopes in Velké Bílovice, such as Nová hora, Zadní hora and Přední hora; or even worse in Mikulov, where the slopes are steeper, such as Anenský vrch, Liščí vrch and Milovická. A study from southwestern France shows that maintaining complete grass cover can keep larval density of grape moths below the threshold and decrease the use of herbicides required for keeping bare soil [22]. Increased competition for water and nutrients between cover crops and grapevines forces grapevine root systems to explore deeper soil layers, where there is higher water availability for the grapevines - especially during drought periods [23].

One of the reasons for the higher proportion of cropland within vineyard sites can be the fact that even unsuitable areas were classified as vineyard sites (basins), such as Nad Peklem in Valtice. Some authors suggest that arable soils may be the main source of fungal inoculum of entomopathogenic fungi attacking overwintering pupae of European grapevine moth (Lobesia botrana Denis \& Schiffermüller, 1775), compared with semi-natural habitats [19], thus some proportion of crop land within vineyard sites can be beneficial.

\section{Relation of Land-Use to Locality (Region)}

Congruently with Fig. 2, the ordination analysis diagram (Fig. 3) shows that Valtice and Znojmo have the largest area of cropland. The regions of Strážnice, Mikulov and Bzenec can be regarded as similar in terms of the proportion of non-crop vegetation areas. The Velké Bílovice region can be mostly related to bare soil vineyards. Ordination analysis (Fig. 3, explanatory variables account for 9.1\%, pseudo $\mathrm{F}=4, \mathrm{P}=0.001$ ) shows that the regions of Bzenec, Strážnice and Mikulov have a similar character in terms of landscape diversity level, while on the other hand, Valtice and Znojmo have a lower diversity landscape, defined by a higher proportion of cropland. Velké Bílovice, with a high proportion of bare soil vineyards and a low proportion of non-crop vegetation, can be regarded as low in landscape diversity. Although vineyards with alternate greening or full area crop where included in primary analysis, no correlation to location was found, thus they were not included in ordination analysis.

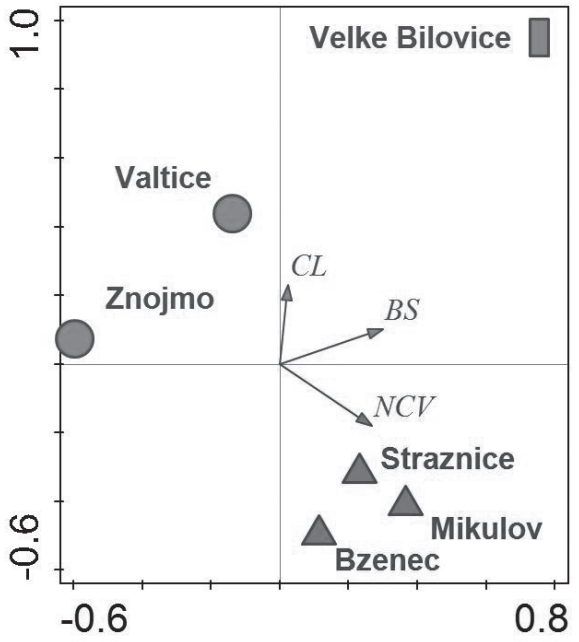

Fig. 3. Ordination diagram of the relationship between land-use and locality (explanatory variables account for $9.1 \%$, pseudo $\mathrm{F}=4, \mathrm{P}=0.001$ ); explanatory notes: BS- bare soil, $\mathrm{CL}$ - cropland, $\mathrm{NCV}$ - non-crop vegetation.

Due to the high proportion of cropland and the low proportion of non-crop vegetation, the region of Valtice, followed by Znojmo, resemble agricultural land and they do not provide sufficient conditions for the support of higher landscape diversity (Fig. 3). The Velké Bílovice region, where even though the total area of bare soil vineyards (144 ha) is almost the same as the Mikulov region (145 ha), and the relative proportion is lower than in Mikulov, which due to the low abundance of non-crop vegetation is considered a less diverse landscape with some similarities to the Valtice region (Fig. 3).

On the other hand, the high proportion of non-crop vegetation in the Mikulov (12\%) and Strážnice regions (8\%) supports increased landscape diversity. Higher abundance of woody non-crop vegetation is considered to be a better source of natural enemies (e.g., against the pest Prays oleae (Bernard, 1788) in olive groves in Spain) than small areas within the crop [24]. Aside from a number of studies describing a positive effect of non-crop vegetation $[1,3,7,9,21]$, according to several authors landscape complexity positively affects natural enemies' abundance but had no effect on pest abundance $[25,26]$. Although the proportion of non-crop vegetation is not so high in Bzenec (6\%), the low proportion of bare soil vineyards $(3 \%)$ creates a character closer to the Mikulov or Strážnice regions (Fig. 3). The use of cover crops in the vineyards with adjacent seminatural (in the $250 \mathrm{~m}$ radius) woody vegetation provides higher avian predation of caterpillars [22]. However, the adjacent natural and semi-natural vegetation in perennial crops seems to have a greater positive effect on natural enemies' abundance than local management (groundcover); the use of cover crops intensifies the positive effect and enables faster movement of natural enemies into the crop [27]. 
Nevertheless, in every region there are still lots of vineyard sites underused for growing grapevines and with suitable conditions (e.g., Valtice), which are potential localities for new vineyard plantation. From the case study of environmental modelling of climate change and its impact on grapevines, the total area with suitable conditions should increase by $10 \%$ in 2050 [28]. The extension of the vineyard sites depends on EU policy regulations, but such an increase of suitable area gives a potential to create new vineyard sites. With character of new plantations which can either be vineyards with inter-row cover crops, biocorridors and non-crop vegetation or bare soil monocultural vineyards, positive or negative changes in landscape diversity can be expected.

\section{Conclusions}

The results show that even though integrated production is dominant in the Czech Republic's vineyards, the differences in evaluated parameters are considerable. With lots of studies and programmes focused on increasing landscape diversity, there still remain vineyard sites where some proportion of noncrop vegetation or cover crops - which provide many of benefits such as soil erosion decrease, higher fauna and flora biodiversity and better nutrient and water cycling - should be introduced. More research is needed to better understand the complexity of relationships within agroecosystems and the impacts of landscape diversity under local conditions.

\section{Acknowledgements}

This research was carried out with financial support of the Internal Grant Agency: IGA - ZF/2018-DP007: Application of the innovation methods of statistical analyses for reaching and realization of $\mathrm{Ph} . \mathrm{D}$. thesis outputs.

\section{Conflict of Interest}

The authors declare no conflict of interest.

\section{References}

1. CARlos C., ALFONSO S., CRESPÍ A., ARANHA J., THISLEWOOD H., TORRES L. Biodiversity of plants and arthropods in key ecological structures of vineyards of the Alto Douro region. IOBC/wprs Bulletin. 75, 51, 2012.

2. BOMMARCO R., KLEIJN D. AND POTTS S. Ecological intensification: harnessing ecosystem services for food security. Trends in Ecology \& Evolution, 28 (4), 230, 2013.

3. ALTIERI M.A., NICHOLLS C.I. Biodiversity and pest management in agroecosystems. $2^{\text {nd }}$ ed. New York: Food Producss Press, ISBN 15-602-2923-3, 2004.
4. MEZIÈRE D., GARY C., BARBIER J.M., BERNOS L., CLÉMENT C., CONSTANT N., DELIÈRE L., FORGET D., GROSMAN J., MOLOT B., RIO P., SAUVAGE D., SENTENAC G. Ecophyto $r$ \& d, towards pesticide-saving cropping systems, part 1 volume III: Comparative analysis of different systems in viticulture. MEEDAT - MAP INRA, 2009 [In French].

5. HLUCHÝ M., LAŠTŮVKA Z. A POSPÍŠIL Z. The Impact of ecological viticulture for nature and landscape protection. In RegioM: Yearbook of Regional Museum in Mikulov. Regional Museum in Mikulov, funded organization, Mikulov, 4, ISBN 978-80-85088-38-0, 2010 [In Czech].

6. RUSCH A., VALANTIN-MORISON M., SARTHOU J.P., ROGER-ESTRADE J.P. Biological Control of Insect Pests in Agroecosystems: Effects of crop management, farming systems, and semi-natural habitats at the landscape scale. A Review. Adv. Agron. 109, 219, 2010.

7. ALTIERI M.A., NICHOLLS C.I., WILSON H., MILES A. Habitat management in vineyards: a growers' manual for enhancing natural enemies of pests. Laboratory of Agroecology/ University of California, Berkeley, 2010.

8. GARY C., METRAL R., METAY A., GARCIA L., MEROT A., SMITS N., WÉRY J. Towards an agroecological viticulture: advances and challenges. In: Proceedings of the 20th GiESCO International Meeting. Book of Full Manuscripts /Libro de Manuscritos Completos, pp. 1122-1127. Presented at 20. GiESCO International Meeting, Mendoza, ARG (2017-11-05-201711-10), 2017.

9. ALTIERI M.A., NICHOLLS C.I., PONTI L., YORK A. Designing biodiverse, pest-resilient vineyards through habitat management. Practical Winery and Vineyard, 27 (2), 16, 2005.

10. RUSCH A., CHAPLIN-KRAMER R., GARDINER M., HAWRO V., HOLLAND J., LANDIS D., THIES C., TSCHARNTKE T., WEISSER W., WINQVIST C., WOLTZ M., BOMMARCO R. Agricultural landscape simplification reduces natural pest control: A quantitative synthesis. Agriculture, Ecosystems \& Environment, 221, 198, 2016

11. SCHELLHORN N., GAGIC V., BOMMARCO R. Time will tell: resource continuity bolsters ecosystem services. Trends in Ecology \& Evolution, 30 (9), 524, 2015.

12. BUBLÍKOVÁ L. Situational Outlook: Grapevine and wine, 2017. Available online: http://eagri.cz/public/web/ file/571061/SVZ_Vino_2017.pdf (Accessed 1 Oct. 2018) [In Czech].

13. Act No. 321/2004 Coll. Act on viticulture and viticulture and on amendment of some related acts (Act on viticulture and viticulture). [In Czech].

14. BAUMGARTNER, K., STEENWERTH, K., VEILLEUX, L. Cover-Crop Systems Affect Weed Communities in a California Vineyard. Weed Science, 56 (4), 596, 2008.

15. KOPTA T., POKLUDA R., PSOTA V. Attractiveness of flowering plants for natural enemies. Hort. Sci. (Prague) 39 (2), 89, 2012.

16. ROBLEÑO I., STORKEY J., SOLÉ-SENAN X.O., RECASENS J. Using the response - effect trait framework to quantify the value of fallow patches in agricultural landscapes to pollinators. Appl. Veg. Sci. 21 (2), 267, 2017.

17. Decree No. 254/2010 Coll. Decree establishing a list of wine-growing sub-regions, wine-growing villages and wine-growing routes. [In Czech]. 
18. TER BRAAK C.J.F, ŠMILAUER P. Canoco reference manual and user's guide: software for ordination (version 5.0). Microcomputer Power. Ithaca, NY, USA, 496, 2012.

19. SCHADER C., PFIFFNER L., SCHLATTER C., STOLZE M. Implementation of ecological measures on organic and ÖLN farms. Agricultural Research Switzerland 15 (10), 506, 2008. [In German].

20. GIBSON R., PEARCE S., MORRIS R., SYMONDSON W., MEMMOTT J. Plant diversity and land use under organic and conventional agriculture: a whole-farm approach. Journal of Applied Ecology, 44 (4), 792, 2007.

21. BOLLER E.F., HÄNI F., POEHLING H-M. Ecological infrastructures: Ideabook on functional biodiversity at the farm level. Temperate zones of Europe. Swiss Centre for Agricultural Extenstion and Rural Development, Switzerland, 212, 2004.

22. RUSCH A., DELBAC L., THIÉRY D. Grape moth density in Bordeaux vineyards depends on local habitat management despite effects of landscape heterogeneity on their biological control. Journal of Applied Ecology, 54 (6), 1794, 2017.

23. CELETTE F,. GAUDIN R., GARY C. Spatial and temporal changes to the water regime of a mediterranean vineyard due to the adoption of cover cropping. Eur J Agron 28 (4), $153,2008$.

24. PAREDES D., CAYUELA L., GURR G., CAMPOS M. Effect of non-crop vegetation types on conservation biological control of pests in olive groves. PeerJ 1: e116., 2013.

25. RUSCH A., DELBAC L., MUNERET L., THIÉRY, D. Organic farming and host density affect parasitism rates of tortricid moths in vineyards. Agriculture, Ecosystems \& Environment, 214, 46, 2015.

26. CHAPLIN-KRAMER R., O'ROURKE M., BLITZER, E., KREMEN, C. A meta-analysis of crop pest and natural enemy response to landscape complexity. Ecology Letters, 14 (9), 922, 2011.

27. PAREDES D., CAYUELA L., CAMPOS M. Synergistic effects of ground cover and adjacent vegetation on natural enemies of olive insect pests. Agriculture, Ecosystems \& Environment, 173, 72, 2013.

28. MACHAR I., VLČKOVÁ V., BUČEK A., VRUBLOVÁ K., FILIPPOVOVÁ J., BRUS J. Environmental Modelling of Climate Change Impact on Grapevines: Case Study from the Czech Republic. Polish Journal of Environmental Studies, 26 (4), 1927, 2017. 
